\title{
Diagnostic Value of Autoantibodies in Lung Cancer: a Systematic Review and Meta- Analysis
}

\author{
Jiangyue Qin Ni Zeng Ting Yang Chun Wan Lei Chen Yongchun Shen \\ Fuqiang Wen
}

Department of Respiratory and Critical Care Medicine, West China Hospital of Sichuan University and Division of Pulmonary Diseases, State Key Laboratory of Biotherapy of China, Chengdu, China

\section{Key Words}

Lung cancer • Tumor-associated autoantibodies • Diagnosis • Meta-analysis

\begin{abstract}
Background/Aims: Recently, many studies have demonstrated that various tumor-associated autoantibodies have been detected in early stages of lung cancer. Therefore, we conducted a meta-analysis to comprehensively evaluate available evidence on the diagnostic value of autoantibodies against tumor-associated antigens in lung cancer. Methods: We systematically searched PubMed, Scopus, Web of Science and other databases through 23 March 2018. Study quality was assessed using the Quality Assessment of Diagnostic Accuracy Studies-2. We used the bivariate mixed-effect models to calculate pooled values of sensitivity, specificity, positive likelihood ratios, negative likelihood ratios, diagnostic odds ratios and associated $95 \%$ confidence intervals. Summary receiver operating characteristic (SROC) curves were used to summarize overall test performance. Deek's funnel plot was used to detect publication bias. Results: Review of 468 candidate articles identified fifty-three articles with a total of 11,515 patients for qualitative review and meta-analysis. Pooled sensitivity, specificity and area under the SROC curve were as follows for tumor-associated autoantibodies against the following proteins: p53, 0.19, 0.98, 0.82; NY-ESO-1, 0.17, 0.98, 0.90; Survivin, 0.19, 0.99, 0.96; c-myc, 0.14, 0.98, 0.45; Cyclin B1, 0.18, 0.98, 0.91; GBU4-5, 0.07, 0.98, 0.91; CAGE, 0.14, 0.98, $0.90 ; \mathrm{p} 16,0.08,0.97,0.91 ; \mathrm{SOX} 2,0.14,0.99,0.93$; and HuD, 0.17, 0.99, 0.82. Conclusion: Each tumor-associated autoantibody on its own showed excellent diagnostic specificity for lung cancer but inadequate sensitivity. Our results suggest that combinations or panels of tumorassociated autoantibodies may provide better sensitivity for diagnosing lung cancer, and the diagnostic accuracy of tumor-associated autoantibodies should be validated in more studies.




\section{Introduction}

Lung cancer is the leading cause of cancer death in both men and women worldwide, accounting for 1.8 million new cases and 1.6 million deaths annually [1,2]. Most lung cancers are detected at advanced stages, reducing the likelihood of cure. The 5-year survival rate, ranging from $50 \%$ for stage IA to $2 \%$ for stage IV, improves significantly when diagnosed at an early stage [3]. Thus, long-term survival in lung cancer depends mainly on early detection and immediate start of treatment [4]. However, there are as yet no effective early detection tools for lung cancer, so patients cannot receive timely treatment, leading to unfavorable clinical outcomes.

Traditional pathological biopsy improves the accuracy of diagnosis, but such invasive procedures can cause the patient substantial inconvenience and pain. The current strategy for lung cancer screening is low-dose computed tomography (LDCT) in high-risk populations. Meta-analysis [5, 6] demonstrated that LDCT is more sensitive in discovering stage I lung cancers and all cancers than chest X-ray or no screening, and has resulted in a $20 \%$ reduction in lung cancer mortality [7]. However, LDCT was apt to possess higher false-positive rates as what the meta-analysis showed, limiting its widespread application as a screening tool [8]. Molecular markers may help identify high-risk populations of lung cancer that may benefit from lung cancer LDCT screening, thereby reducing unnecessary follow-up LDCT scans and radiation exposure. In addition, combination of molecular markers and LDCT screening for diagnosing lung cancer may reduce excessive false positive results [9]. Thus, identifying more reliable and accurate serum tumor markers for lung cancer remains a high priority.

A handful of molecular biomarkers have been applied to clinical testing, such as carcinoembryonic antigen (CEA), neuron-specific enolization enzyme (NSE), cytokeratin 19 fragment (CYFRA21-1), carbohydrate antigen (CA) 125, and CA199. However, these molecules are rarely used as early biomarkers because of their low sensitivity and specificity, and because false-positive results can occur as a result of infection, benign tumors, pregnancy, and other factors [10].

Lung cancers can trigger host immune responses and elicit antibodies against tumor antigens [11]. This response occurs because these tumor-associated antigens (TAAs) are altered to some degree. They may be mutated (e.g. p53) [12], misfolded [13], overexpressed (e.g. NY-ESO-1) [14], aberrantly degraded [15] or aberrantly glycosylated (e.g. MUC-1) [16]. Compared with the traditional lung cancer serological markers, antibodies against TAAs, called tumor-associated autoantibodies (TAAbs), have unique advantages. First of all, TAAbs have been detected not only at initial diagnosis of lung cancer [17], but also, in some cases, up to 5 years before cancer is diagnosed $[18,19]$, whereas TAAbs are absent or present at low levels in serum of healthy people and in patients with benign pulmonary tumors. Secondly, TAAbs have long half-lives in serum. Thirdly, especially in the early stage of tumor development, TAAb levels in serum are much higher than levels of TAAs [20].

The aim of this meta-analysis was to summarize the available evidence on the overall accuracy of TAAbs for the diagnosis of lung cancer.

\section{Materials and Methods}

\section{Search strategy and study selection}

The systematic review was conducted according to the Preferred Reporting Items for Systematic Reviews and Meta-Analysis (PRISMA) guidelines [21]. Two investigators (QJY and ZN) independently searched PubMed, Scopus, Web of Knowledge, Chinese National Knowledge Infrastructure (CNKI), Wanfang and Weipu databases without time limitations. The last search was conducted on 23 March 2018. The following retrieval strategy was used: "autoantibody or autoantibodies" and "lung cancer or lung carcinoma or lung neoplasm or pulmonary cancer or cancer of lung" and "sensitivity or specificity or accuracy". In addition, the reference lists of eligible articles were manually searched by the two investigators independently in order to obtain additional studies. 


\section{Cellular Physiology Cell Physiol Biochem 2018;51:2631-2646 \begin{tabular}{ll|l} 
and Biochemistry & $\begin{array}{l}\text { DOl: 10.1159/000495935 } \\
\text { Published online: } 11 \text { December } 2018\end{array}$ & $\begin{array}{l}\text { (2018 The Author(s). Published by S. Karger AG, Basel } \\
\text { www.karger.com/cpb }\end{array}$ \\
\cline { 2 - 3 }
\end{tabular} \\ Qin et al.: Diagnostic Performance of TAAbs in LC}

Two authors (QJY and ZN) independently assessed each study for eligibility. Discrepancies were resolved by consultation with a third author (SYC). Studies were included in the review if they fulfilled all the following criteria: (1) the work was an original research article published in English or Chinese; (2) human samples were analyzed; (3) the study examined TAAbs for diagnosing lung cancer and contained a control group; and (4) sufficient data were reported to calculate true positive (TP), false positive (FP), false negative (FN), and true negative (TN) rates for TAAbs. Case reports or case series involving fewer than 10 patients, conference proceedings, reviews, letters to the editor, and case reports were excluded because of the limited data reported.

\section{Quality assessment and data extraction}

The quality of the included studies was scored independently by two authors (QJY and ZN) according to the criteria of the Revised Tool for the Quality Assessment of Diagnostic Accuracy Studies-2 (QUADAS-2) [22]. Four key domains were assessed (patient selection, index test, reference standard, flow and timing), and each domain contained seven "yes/no/unclear" questions. The following data were retrieved from each study: authors, country, tumor type, specimen type, gold standard, assay methods, and 2-by-2 tables showing rates of TP, TN, FP and FN. Detailed information about controls was also extracted. Controls in the included studies were either healthy or they had benign pulmonary diseases.

\section{Data synthesis and analysis}

Data were completed in Excel, then transferred to STATA 14.0 (Stata, College Station, TX, USA) and Review Manager 5.2 (The Cochrane Collaboration, Copenhagen, Denmark) for statistical analysis. For each study, pooled sensitivity and specificity and their 95\% confidence intervals (CIs) were calculated using the bivariate random-effects model [23]. To provide potentially more clinically relevant outcomes, we also calculated for each TAAb a likelihood ratio, diagnostic odds ratio (DOR), and area under the curve (AUC).

Two authors (QJY and ZN) assessed studies for possible overlap in the populations analyzed. Data were pooled from overlapping populations as long as the different studies reported on different TAAbs or TAAb combinations. Otherwise, if studies with overlapping populations reported on the same TAAbs or TAAb combination, only the data from the largest study were used.

Heterogeneity induced by the nonthreshold effect was assessed using the Cochran Q method and the test of inconsistency $\left(\mathrm{I}^{2}\right)$. If $\mathrm{P}<0.05$ or $\mathrm{I}^{2}>50 \%$, heterogeneity exists [24]. Furthermore, subgroup and regression analyses were performed to explore potential sources of heterogeneity. Deeks' test was used to detect publication bias. All $\mathrm{P}$ values were calculated using a 2 -tailed test, and $\mathrm{P}<0.05$ was regarded as statistically significant.

\section{Results}

\section{Basic information about the included studies}

A total of 468 articles were initially identified, of which 327 were excluded as duplicates, reviews, news reports, meeting records or other publication types that did not focus on lung cancer (Fig. 1). In the end, 53 articles were included, which examined the diagnostic efficacy of TAAbs against p53, c-myc, Survivin, NY-ESO-1, Cyclin B1, CAGE, GBU 4-5, p16, HuD and SOX2 [17, 25-76]. Other TAAbs were excluded from the review because relevant data were available from fewer than 3 articles [77-108]. Five of the included studies examined only small-cell lung cancer (SCLC) $[45,50,52,58,67]$, and eight included only non-small cell lung cancer (NSCLC) $[28,47,54,55,57,59,64,109]$. A total of 50 articles were based on serum specimens, while the remaining 3 were based on plasma samples. In 41 articles, diagnosis of lung cancer was based on histopathology or cytology; 12 articles did not report the standards used to diagnose lung cancer. A total of 50 articles measured TAAb levels using enzyme-linked immunosorbent assays (ELISAs), and the remaining 3 articles using immunoblotting (Supplementary Table 1 - for all supplemental material see www.karger. com/10.1159/000495935/). Mean absorbance or level of TAAbs in the control group plus 2-3 standard deviations (SDs) were used to identify positive samples. 


\section{Study quality}

QUADAS-2 assessment of included studies showed that most studies had low risk of bias (Fig. 2 and Fig. 3 ) and that the studies were suitable for quantitative synthesis.

\section{Diagnostic performance of single TAAbs}

Data were metaanalyzed using a bivariate model (Table 1). The metaanalysis showed that overall sensitivity of all TAAbs was low: TAAb against p53, 0.19 (95\%CI 0.15-0.23); NY-ESO- $1, \quad 0.17 \quad$ (95\%CI 0.10-0.26); Survivin, 0.19 (95\%CI 0.12-0.29); c-myc, 0.14 (95\%CI 0.11-0.18); HuD, 0.17 (95\%CI $0.12-$ $0.24)$; SOX2, $0.14 \quad(95 \% \mathrm{CI}$ $0.06-0.30)$; Cyclin B1, 0.18 (95\%CI 0.14-0.24); CAGE, 0.14 (95\%CI 0.09-0.21); GBU 4-5, 0.07 (95\%CI 0.02-0.22); and p16, 0.08 (95\%CI 0.03-0.22). In contrast, the TAAbs showed excellent pooled specificity: p53, 0.98 (95\%CI 0.97-0.98); NY-ESO-1, 0.98 (95\%CI 0.96-0.99); Survivin, 0.99 (95\%CI 0.97-0.99); c-myc, 0.98 (95\%CI 0.96-0.99); HuD, 0.99 (95\%CI 0.98-1.00); SOX2, 0.99 (95\%CI 0.97-0.99); Cyclin B1, 0.98 (95\%CI 0.96-0.99); CAGE, 0.98 (95\%CI 0.96-0.99); GBU 4-5, 0.98 (95\%CI 0.94-0.99); and p16, 0.97 (95\%CI 0.94-0.99). AUCs were as follows: p53, 0.82 (95\%CI 0.79-0.85); NY-ESO-1, 0.90 (95\%CI 0.87-0.92); Survivin, 0.96 (95\%CI 0.930.97); c-myc, 0.45 (95\%CI 0.41-0.49); HuD, 0.82 (95\%CI 0.79-0.85); SOX2, 0.93 (95\%CI 0.90-0.95); Cyclin B1, 0.91 (95\%CI 0.88-0.93); CAGE, 0.90 (95\%CI 0.87-0.92); GBU 4-5, 0.91 (95\%CI 0.88-0.93); and p16, 0.91 (95\%CI 0.88-0.93). The SROC curve was generated for the four TAAbs reported by the largest number of studies (Survivin, p53, NY-ESO-1, c-myc), allowing overall assessment of diagnostic performance (Fig. 4).

\section{Diagnostic performance of p53 TAAb for early stage I/II lung cancer}

We also focused on the diagnostic value of TAAb for early stage lung cancer. Six studies on p53 TAAb [29, 30, 37, 39, 40,51] were included for the meta-analysis, which reported the positive rate for this TAAb in different stages of lung cancer. The pooled sensitivity and specificity of p53 TAAb for early stage I/II lung cancer was 0.13 (95\%CI 0.04-0.33) and 0.98 (95\%CI 0.95-0.99), respectively. The AUC was 0.93 (95\%CI 0.90-0.95), indicating a relatively high level of overall diagnostic accuracy of p53 TAAb for early stage lung cancer. Other TAAbs were not analyzed because fewer than three studies reported the positive rates of these TAAbs in different stages of lung cancer.

\section{Subgroup analyses}

Mutations in the p53 gene are present in up to $50 \%$ of NSCLC cases and $80 \%$ of SCLC cases [110]. Therefore we performed subgroup analysis to identify whether the presence of p53 TAAb could differentiate NSCLC (15 studies, 2, 478 patients) and SCLC ( 9 studies, 1, 630 patients). We also examined whether the same was true for NY-ESO-1 TAAb. The 


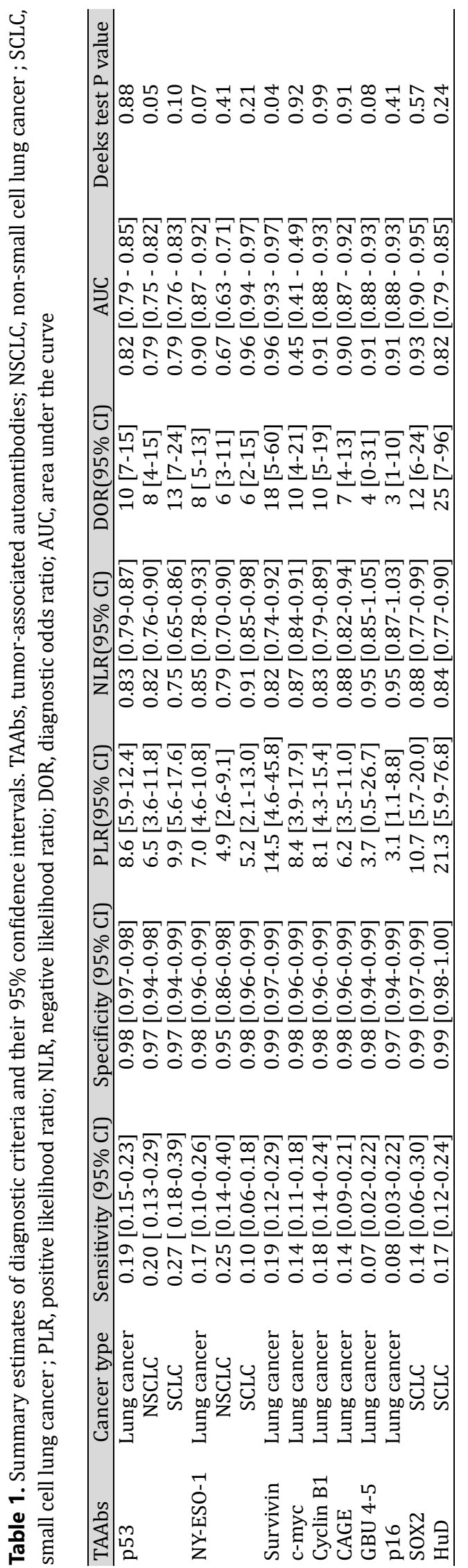

results suggest that both TAAbs show greater diagnostic efficiency for SCLC than for NSCLC, albeit with low diagnostic efficacy (Table 1).

We also compared the diagnostic performance of p53 TAAb depending on whether the reference (control) group was healthy individuals or patients with chronic pulmonary disease. The p53 TAAb showed the following diagnostic parameters against healthy controls: sensitivity, 0.18 (95\%CI 0.13-0.24); specificity, 0.98 (95\%CI 0.97 0.98); PLR, 7.7 (95\%CI 5.8-10.3); NLR, 0.84 (95\%CI 0.79-0.89); DOR, 9 (95\%CI 7-13); and AUC, 0.92 (95\%CI 0.89-0.94). In contrast, the parameters against patients with chronic pulmonary disease were as follows: sensitivity, 0.16 (95\%CI 0.12-0.21); specificity, 0.97 (95\%CI 0.93-0.98); PLR, 4.9 (95\%CI 2.4-9.8); NLR, 0.87 (95\%CI 0.82-0.91); DOR, 6 (95\%CI 3-12); and AUC, 0.54 (95\%CI 0.5-0.58). These results suggest that, at least in the case of the p53 TAAb, using healthy individuals as controls provides higher diagnostic efficiency than using patients with chronic pulmonary disease.

\section{Meta-regression analyses}

Significant heterogeneity existed among studies of the p53 TAAb: $\mathrm{I}^{2}$ values were $91.63 \%$ for sensitivity, $69.11 \%$ for specificity (Fig. 5), $13.88 \%$ for PLR, $85.48 \%$ for NLR and $100 \%$ for DOR (all $\mathrm{P}<0.05$ ). Therefore we conducted meta-regression analysis for data on this TAAb in which the odds ratio (OR) was used for binary classification of data, and log OR was used as the response variable. The covariates were the patient's geographic region, type of sample and assay method. The residual $\mathrm{I}^{2}$ $\left(\mathrm{I}^{2}\right.$-res) value was $29.74 \%$, suggesting that $29.74 \%$ of the residual variation could be explained by the heterogeneity, while the remaining $70.26 \%$ was explained among the studies. The adjusted R-squared was $41.92 \%$ in the covariate model, which may explain the variation among the studies. This variation may relate to the patient's geographic region $(\mathrm{P}=0.034$; Table 2), but it was not related to type of sample or assay method. Thus we conducted subgroup analysis of p53 TAAb performance based on the patient's geographic region (Table 3). Conclusive cut-off values could not be identified in this regression because of inaccurate data and the lack of a uniform standard. Meta-regression analysis was not performed for other TAAbs because of the limited number of studies. 


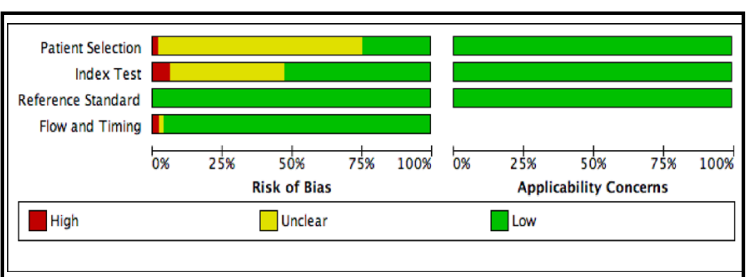

Fig. 2. Methodological quality graph.

Diagnostic performance of TAAb combinations

The included studies reported sufficient data to examine the diagnostic performance of two combinations of TAAbs. One combination was TAAbs against p53, NY-ESO1, CAGE, GBU45, Annexin 1 and SOX2 [48, 53, 111-113], which showed estimated sensitivity of 0.38 (95\% CI $0.35-0.40)$ and specificity of 0.89 (95\% CI 0.86-0.91). The other combination was TAAbs against p53, CAGE, NY- ESO-1, GBU4-5, SOX2, MAGE A4 and $\operatorname{HuD}[2,53,111,114]$, which showed estimated sensitivity of 0.47 (95\% CI $0.34-0.60)$ and specificity of $0.90(95 \% \mathrm{CI}$ 0.89-0.92).

\section{Sensitivity analysis}

Sensitivity analysis for p53 TAAb was performed to make sure that our findings were not overly influenced by any single study (Fig. 6). Comparison of pooled diagnostic parameters using all studies or all studies except for three outliers [33, 36, 37] showed that excluding the three studies reduced sensitivity from 0.19 to 0.17, DOR from 10 to 9 and PLR from 8.6 to 7.9, whereas it increased NLR from 0.83 to 0.85 and AUC from 0.82 to 0.91 . Specificity in both cases was 0.98. Excluding the three studies reduced the $\mathrm{I}^{2}$ for heterogeneity in sensitivity from $91.63 \%$ to $89.47 \%$ and in specificity from $69.11 \%$ to $31.03 \%$. These results suggest that our meta-analysis with the full set of studies is reliable.

\section{Publication bias evaluation}

Except for studies of p53 TAAb and Survivin TAAb for diagnosing NSCLC and lung cancer, respectively, Deeks' funnel plots showed no evidence of publication bias for the TAAbs (all P > 0.05; Table 1).

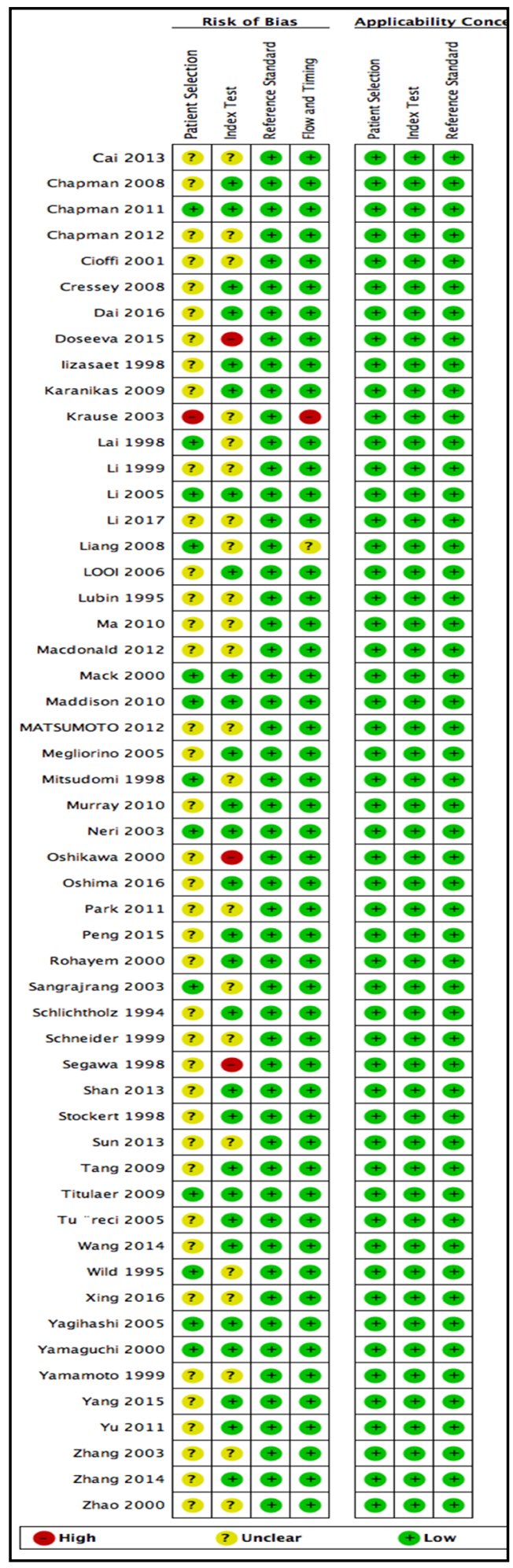

Fig. 3. Methodological quality summary. 
Fig. 4. Summary receiver operating characteristic (SROC) curve of autoantibodies for the diagnosis of lung cancer. a) Anti-Survivin a u to a n t ib ody, b) anti-p53 autoantibody, c) a n ti-NY-ES O- 1 a u to a n tibody, d) anti-c-myc autoantibody. The number in each circle corresponds to the number of studies.

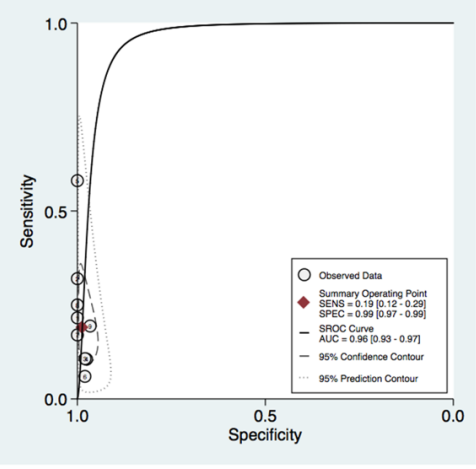

(a)

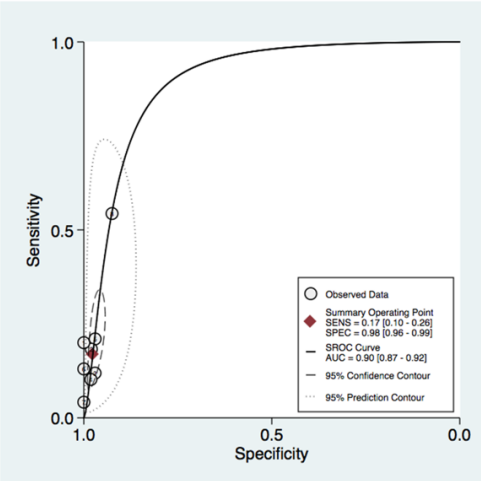

(c)

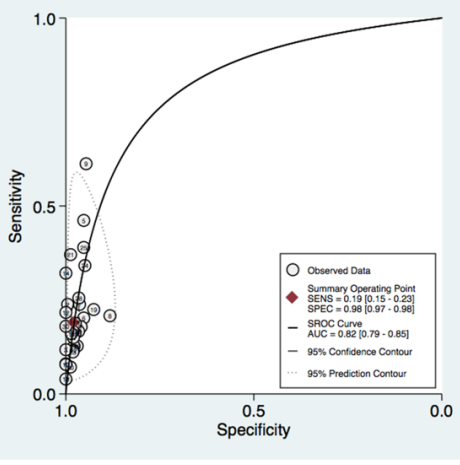

(b)

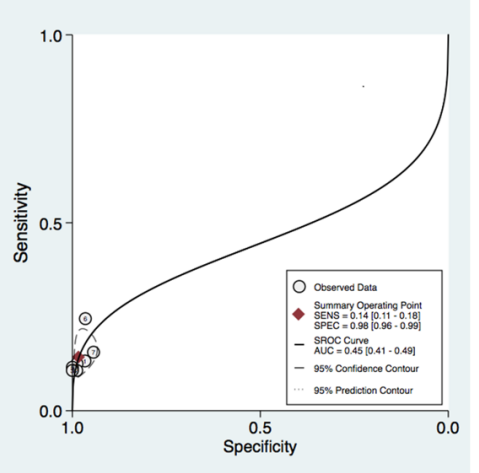

(d)

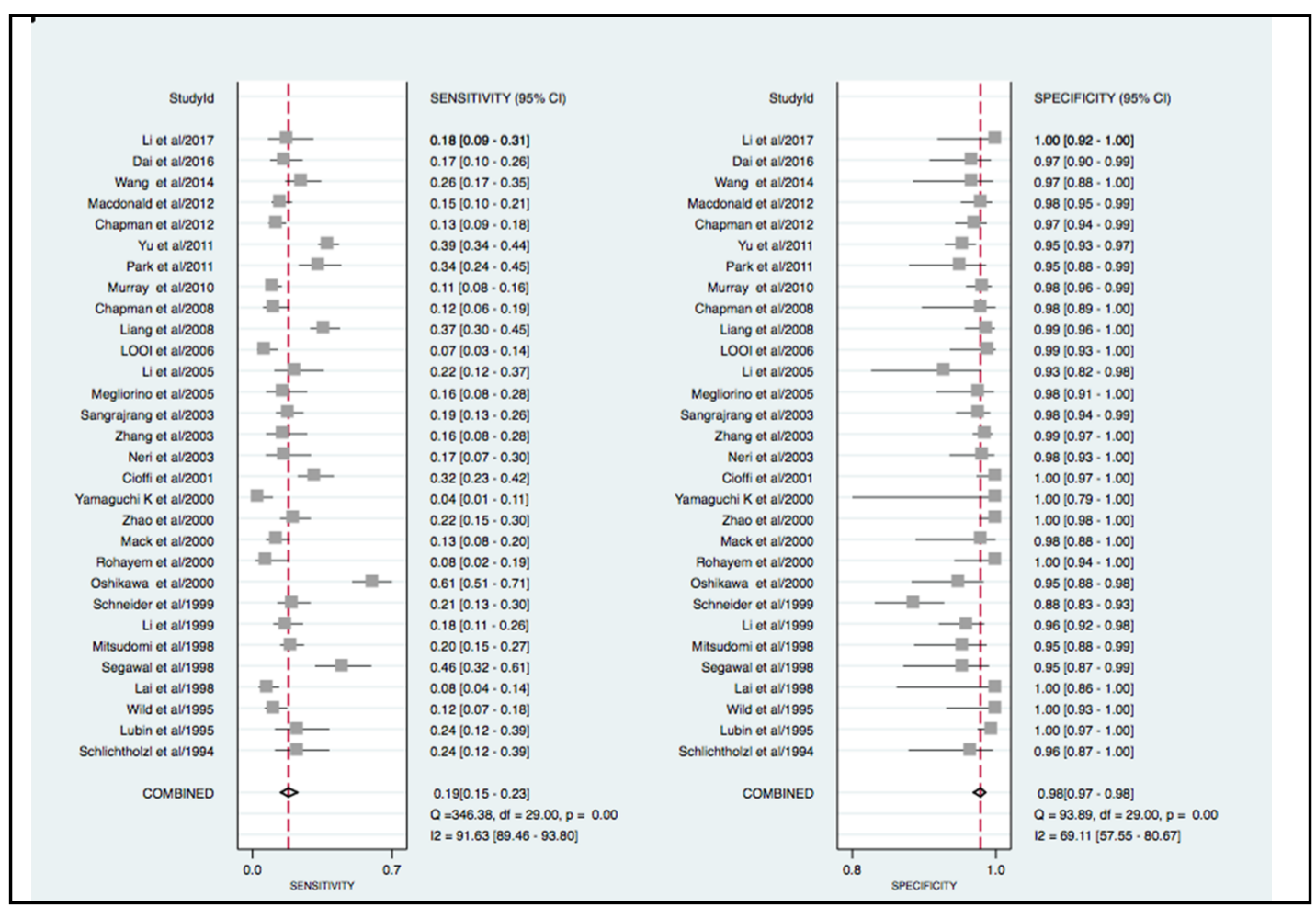

Fig. 5. Forest plot of diagnostic accuracy index of p53 TAAb in lung cancer. Sensitivity and specificity of p53 $\mathrm{TAAb}$ in diagnosis of lung cancer. The point estimates the sensitivity and specificity among the studies as solid squares. Error bars with 95\% confidence intervals (CIs). 
Table 2. Using the odds ratio (OR) for the meta-regression analysis in the binary classification of variable data. LogOR was used as response variables as well as ethnicity, specimen and method were as covariates Estimate of between-study variance tau $2=0.1712$. Residual variation due to heterogeneity: I-squared_res = $29.74 \%$. Proportion of between-study variance explained: Adj R-squared $=41.92 \%$. Joint test for all covariates with Knapp-Hartung modication: Prob > F = 0.1387

\begin{tabular}{llccccc}
\hline LogOR & $\exp (\mathrm{b})$ & Std.Err & $\mathrm{t}$ & $\mathrm{P}>|\mathrm{t}|$ & [95\%Conf.Interval] \\
\hline Patient's geographic region & .5033167 & .1545677 & -2.24 & 0.034 & .2677276 & .9462143 \\
Type of sample & 1.157628 & .6786082 & 0.25 & 0.805 & .3469447 & 3.862583 \\
Assay method & 2.782821 & 4.275418 & 0.67 & 0.511 & .1182953 & 65.46406 \\
_cons & 3.847993 & 6.275298 & 0.83 & 0.416 & .1347142 & 109.9146 \\
\hline
\end{tabular}

Table 3. Subgroup analysis of geographic region for p53 autoantibody. PLR, positive likelihood ratio; NLR, negative likelihood ratio;DOR, diagnostic odds ratio

\begin{tabular}{|c|c|c|c|c|c|c|}
\hline Geographic region & Number of studies & $\mathrm{I}^{2}$ for sensitivity & $\mathrm{I}^{2}$ for specificity & $\mathrm{I}^{2}$ for PLR & $I^{2}$ for NLR & $\mathrm{I}^{2}$ for $\mathrm{DOR}$ \\
\hline Total & 30 & 91.63 & 69.11 & 13.88 & 85.48 & 100 \\
\hline Asia & 14 & 92.88 & 36.01 & 0 & 89.40 & 90.37 \\
\hline Non-Asia & 16 & 69.59 & 79.06 & 13.29 & 53.33 & 99.99 \\
\hline
\end{tabular}

\section{Discussion}

The mortality of lung cancer is due primarily to late detection; early diagnosis is crucial for asymptomatic patients. TAAbs can be detected in many cancer patients prior to symptom onset $[17,48]$, raising the possibility that they may facilitate early diagnosis. Indeed, healthy people usually lack these TAAbs, even those at higher risk of lung cancer. These promising characteristics have led many researchers to explore the diagnostic potential of assaying TAAbs in peripheral blood as serological markers of lung cancer.

One recent review [109] indicated different single or combinations of multiple TAAbs have different diagnostic abilities for detecting patients at all stages of lung cancer, while the review did not report sensitivity, specificity and AUC for each TAAb. In our systematic review, each TAAb was analyzed using bivariate mixedeffect models, and larger numbers of references were included. Our systematic review of the available evidence suggests that TAAbs against p53, NY-ESO-1, Survivin, c-myc, HuD, SOX2, Cyclin B1, CAGE, GBU 4-5 and p16 show high specificity for diagnosing lung cancer but insufficient sensitivity. For example, PLRs were $>10$ (indicating $>10$-fold difference between pre- and post-test) only for TAAbs against Survivin, HuD, or SOX2 (Table 1). This means that a positive result for any of these TAAbs indicates a relatively high probability of lung cancer, which is consistent with the high specificities reported for these TAAbs. However, the NLRs 
for these TAAbs were not low, indicating an inability to exclude the possibility of lung cancer. SCLC progresses rapidly and disseminates widely, giving rise to low 5-year survival [115]. Most cases of SCLC (60-70\%) are diagnosed at the extensive stage, reducing the possibilities for good prognosis [116-118]. This highlights the urgent need to develop serum biomarkers that might allow diagnosis of SCLC. Our meta-analysis suggests that p53 and NY-ESO-1 TAAbs show better diagnostic performance for SCLC than for NSCLC. A previous study suggested that the Hu TAAb may be useful in early diagnosis of SCLC [119]. Therefore future studies should investigate whether combining TAAbs against Hu, p53 and NY-ESO-1 can facilitate SCLC diagnosis.

The EarlyCDT $®$-Lung Test is a novel TAAb diagnostic test for the early detection of lung cancer allowing stratification of individuals according to their risk of developing lung cancer, which could permit a targeted approach to LDCT scanning for early lung cancer detection. The EarlyCDT®-Lung Test measures seven TAAbs against p53, NY-ESO-1, CAGE, GBU4-5, HuD, MAGE A4 and SOX2, which identify $47 \%$ of lung cancers with a high specificity of $90 \%[2$, $53,111,114]$. Moreover, the TAAbs detected in the test have not been shown to vary with age, gender or ethnicity [120], making the test more suitable for clinical screening. However, combinations of TAAbs may be associated with higher sensitivity but lower specificity than single TAAbs.

Survivin is an apoptosis-suppressing protein, promoting cell proliferation and inhibiting apoptosis $[121,122]$. Once Survivin is overexpressed in lung cancer, it may lead to antibody responses to this protein. Antibodies to Survivin are one of the tumor-associated autoantibodies described most frequently in lung cancer $[123,124]$. Our analysis shows that AUC and specificity of Survivin are relatively high. Future research should examine wehther Survivin should be included in the EarlyCDT®-Lung Test.

The present meta-analysis has some limitations. First, our exclusion of conference abstracts, letters to journal editors and unpublished data may have given rise to publication bias, such that our results overestimate actual diagnostic performance. Second, description of methodology was incomplete in some studies, leading to a QUADAS-2 assessment of "unclear". Third, a single TAAb was detected in a relatively small population of patients with lung cancer, which means that relying on TAAb individually may lead to a high FN rate. Fourth, most studies used ELISA to analyze serum TAAbs, while diagnostic cut-off values have not been established for lung cancer. Therefore, more researches are needed to confirm the optimized TAAb cut-off values. Fifth, all but one study [41] was retrospective, increasing the risk of bias in patient selection. Sixth, substantial heterogeneity was detected. In the case of studies of p53 TAAb, the heterogeneity reflected cancer type, source of control, and patient's geographic region as well as unidentified factors. Seventh, some studies did not report smoking status, especially in healthy controls, which leads to selection bias. For instance, the prevalence of p53-TAAbs was higher in smokers than in non-smokers [125, 126]. Moreover, smoking status was found to be the major contributor to levels of anti-Survivin TAAbs [127]. Future studies on TAAbs should consider smoking status. Our results highlight the need for more rigorous studies of TAAb combinations in the diagnosis of lung cancer.

\section{Conclusion}

TAAbs show low sensitivity and high specificity as serum diagnostic markers of lung cancer. Our results indicate that combinations or panels of autoantibodies may improve sensitivity but at the cost of specificity. Future research should focus on novel TAAb panels that may offer better diagnostic performance. 


\section{Cellular Physiology Cell Physiol Biochem 2018;51:2631-2646 \begin{tabular}{ll|l} 
and Biochemistry Published onIIne: T1 December 2018 & $\begin{array}{l}\text { (c) } 2018 \text { The Author(s). Published by S. Karger AG, Basel } \\
\text { www.karger.com/cpb }\end{array}$ \\
\hline
\end{tabular} \\ Qin et al.: Diagnostic Performance of TAAbs in LC}

\section{Acknowledgements}

This work was supported by grants from the National Key Research and Development Program in China (2016YFC1304500, 2016YFC0903600, 2016YFC0901100), and National Natural Science Foundation of China (81230001, 81470236, and 81670038), and the funders had no role in study design, data collection and analysis, decision to publish, or preparation of the manuscript.

\section{Disclosure Statement}

The authors declare no potential conflicts of interest.

\section{References}

1 Siegel RL, Miller KD, Jemal A: Cancer Statistics, 2017. CA Cancer J Clin 2017;67:7-30.

-2 Massion PP, Healey GF, Peek LJ, Fredericks L, Sewell HF, Murray A, Robertson JF: Autoantibody Signature Enhances the Positive Predictive Power of Computed Tomography and Nodule-Based Risk Models for Detection of Lung Cancer. J Thorac Oncol 2017;12:578-584.

3 Goldstraw P, Crowley J, Chansky K, Giroux DJ, Groome PA, Rami-Porta R, Postmus PE, Rusch V, Sobin L: The IASLC Lung Cancer Staging Project: proposals for the revision of the TNM stage groupings in the forthcoming (seventh) edition of the TNM Classification of malignant tumours. J Thorac Oncol 2007;2:706714 .

4 Henschke CI, Yankelevitz DF, Libby DM, Pasmantier MW, Smith JP, Miettinen OS: Survival of patients with stage I lung cancer detected on CT screening. N Engl J Med 2006;355:1763-1771.

5 Gopal M, Abdullah Se, Grady JJ, Goodwin JS: Screening for lung cancer with low-dose computed tomography: a systematic review and meta-analysis of the baseline findings of randomized controlled trials. J Thorac Oncol 2010;5:1233-1239.

6 Fu C, Liu Z, Zhu F, Li S, Jiang L: A meta-analysis: is low-dose computed tomography a superior method for risky lung cancers screening population? Clin Respir J 2016;10:333-341.

7 Aberle Dr, Adams AM, Berg CD, Black WC, Clapp JD, Fagerstrom RM, Gareen IF, Gatsonis C, Marcus PM, Sicks JD: Reduced lung-cancer mortality with low-dose computed tomographic screening. The New England journal of medicine 2011;365:395-409.

8 Coureau G, Salmi LR, Etard C, Sancho-Garnier H, Sauvaget C, Mathoulin-Pelissier S: Low-dose computed tomography screening for lung cancer in populations highly exposed to tobacco: A systematic methodological appraisal of published randomised controlled trials. Eur J Cancer 2016; 61:146-156.

-9 Mazzone Pj, Sears CR, Arenberg DA, Gaga M, Gould MK, Massion PP, Nair VS, Powell CA, Silvestri GA, Vachani A, Wiener RS: Evaluating Molecular Biomarkers for the Early Detection of Lung Cancer: When Is a Biomarker Ready for Clinical Use? An Official American Thoracic Society Policy Statement. Am J Respir Crit Care Med 2017; 196:e15-e29.

-10 Zimmerman R, Wahren B, Edsmyr F: Assessment of serial CEA determinations in urine of patients with bladder carcinoma. Cancer 1980;46:1802-1809.

11 Wang J, Shivakumar S, Barker K, Tang Y, Wallstrom G, Park JG, Tsay JC, Pass HI, Rom WN, LaBaer J, Qiu J: Comparative Study of Autoantibody Responses between Lung Adenocarcinoma and Benign Pulmonary Nodules. J Thorac Oncol 2016;11:334-345.

12 Soussi T: p53 Antibodies in the sera of patients with various types of cancer: a review. Cancer Res 2000;60:1777-1788.

13 Schubert U, Anton LC, Gibbs J, Norbury CC, Yewdell JW, Bennink JR: Rapid degradation of a large fraction of newly synthesized proteins by proteasomes. Nature 2000;404:770-774.

14 Chen YT, Scanlan MJ, Sahin U, Tureci O, Gure AO, Tsang S, Williamson B, Stockert E, Pfreundschuh M, Old LJ: A testicular antigen aberrantly expressed in human cancers detected by autologous antibody screening. Proc Natl Acad Sci U S A 1997;94:1914-1918. 


\section{Cellular Physiology Cell Physiol Biochem 2018;51:2631-2646 and Biochemistry Published \begin{tabular}{l|l} 
DOI: 10.1159/000495935 & $\begin{array}{l}\text { (c) } 2018 \text { The Author(s). Published by S. Karger AG, Basel } \\
\text { www.karger.com/cpb }\end{array}$
\end{tabular} \\ Qin et al.: Diagnostic Performance of TAAbs in LC}

15 Ulanet DB, Torbenson M, Dang CV, Casciola-Rosen L, Rosen A: Unique conformation of cancer autoantigen B23 in hepatoma: a mechanism for specificity in the autoimmune response. Proc Natl Acad Sci U S A 2003;100:12361-12366.

16 von Mensdorff-Pouilly S, Petrakou E, Kenemans P, van Uffelen K, Verstraeten AA, Snijdewint FG, van Kamp GJ, Schol DJ, Reis CA, Price MR, Livingston PO, Hilgers J: Reactivity of natural and induced human antibodies to MUC1 mucin with MUC1 peptides and n-acetylgalactosamine (GalNAc) peptides. Int J Cancer 2000;86:702-712.

17 Chapman CJ, Murray A, McElveen JE, Sahin U, Luxemburger U, Tureci O, Wiewrodt R, Barnes AC, Robertson JF: Autoantibodies in lung cancer: possibilities for early detection and subsequent cure. Thorax 2008;63:228-233.

18 Trivers GE, De Benedetti VM, Cawley HL, Caron G, Harrington AM, Bennett WP, Jett JR, Colby TV, Tazelaar H, Pairolero P, Miller RD, Harris CC: Anti-p53 antibodies in sera from patients with chronic obstructive pulmonary disease can predate a diagnosis of cancer. Clin Cancer Res : an official journal of the American Association for Cancer Research 1996;2:1767-1775.

19 Zhong L, Coe SP, Stromberg AJ, Khattar NH, Jett JR, Hirschowitz EA: Profiling tumor-associated antibodies for early detection of non-small cell lung cancer. J Thorac Oncol 2006;1:513-519.

20 Broodman I, Lindemans J, van Sten J, Bischoff R, Luider T: Serum Protein Markers for the Early Detection of Lung Cancer: A Focus on Autoantibodies. J Proteome Res 2017;16:3-13.

21 Liberati A, Altman DG, Tetzlaff J, Mulrow C, Gotzsche PC, Ioannidis JP, Clarke M, Devereaux PJ, Kleijnen J, Moher D: The PRISMA statement for reporting systematic reviews and meta-analyses of studies that evaluate health care interventions: explanation and elaboration. Ann Intern Med 2009;151:W65-94.

22 Whiting PF, Rutjes AW, Westwood ME, Mallett S, Deeks JJ, Reitsma JB, Leeflang MM, Sterne JA, Bossuyt PM: QUADAS-2: a revised tool for the quality assessment of diagnostic accuracy studies. Ann Intern Med 2011;155:529-536.

-23 Reitsma JB, Glas AS, Rutjes AW, Scholten RJ, Bossuyt PM, Zwinderman AH: Bivariate analysis of sensitivity and specificity produces informative summary measures in diagnostic reviews. J Clin Epidemiol 2005;58:982-990.

24 Huedo-Medina TB, Sanchez-Meca J Fau - Marin-Martinez F, Marin-Martinez F Fau - Botella J, Botella J: Assessing heterogeneity in meta-analysis: Q statistic or I2 index? Psychol Methods 2006; 11:193-206.

25 Schlichtholz B, Trédaniel J, Lubin R, Zalcman G, Hirsch A, Soussi T: Analyses of p53 antibodies in sera of patients with lung carcinoma define immunodominant regions in the p53 protein. Br J Cancer 1994;69:809-818.

26 Lubin R, Schlichtholz B, Teillaud JL, Garay E, Bussel A, Wild CP: p53 antibodies in patients with various types of cancer: assay, identification, and characterization. Clin Cancer Res 1995;1:1463-1469.

27 Wild CP, Ridanpää M, Anttila S, Lubin R, Soussi T, Husgafvelpursiainen K, Vainio H: p53 antibodies in the sera of lung cancer patients: comparison with p53 mutation in the tumour tissue. Int J Cancer 1995;64:176-181.

28 Iizasa T, Fujisawa T, Saitoh Y, Hiroshima K, Ohwada H: Serum anti-p53 autoantibodies in primary resected non-small-cell lung carcinoma. Cancer Immunol Immun 1998;46:345-349.

-29 Lai CL, Tsai CM, Tsai TT, Kuo BI, Chang KT, Fu HT, Perng RP, Chen JY: Presence of serum anti-p53 antibodies is associated with pleural effusion and poor prognosis in lung cancer patients. Clin Cancer Res 1998;4:3025-3030.

-30 Mitsudomi T, Hatooka S, Shinoda M, Suyama M, Yatabe Y, Kuwabara M, Nishio M, Gotoh K, Ogawa M, Takahashi T: Clinical Implications of p53 Autoantibodies in the Sera of Patients With Non-Small-Cell Lung Cancer. Jnci-J Natl Cancer I 1998;90:1563-1568.

-31 Segawa Y, Kageyama M, Suzuki S, Jinno K, Takigawa N, Fujimoto N, Hotta K, Eguchi K: Measurement and evaluation of serum anti-p53 antibody levels in patients with lung cancer at its initial presentation: a prospective study. Br J Cancer 1998;78:667-672.

32 Li Y, Brandt-Rauf PW, Carney WP, Tenney DY, Ford JG: Circulating anti-p53 antibodies in lung cancer and relationship to histology and smoking. Biomarkers 1999;4:381-390.

-33 Schneider J, Presek P, Braun A, Bauer P, Konietzko N, Wiesner B, Woitowitz HJ: p53 protein, EGF receptor, and anti-p53 antibodies in serum from patients with occupationally derived lung cancer. Br J Cancer 1999;80:1987-1994. 


\section{Cellular Physiology Cell Physiol Biochem 2018;51:2631-2646

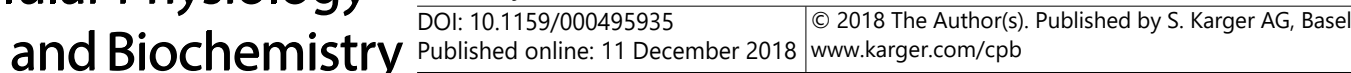 \\ Qin et al.: Diagnostic Performance of TAAbs in LC}

34 Yamamoto A, Shimizu E, Takeuchi E, Houchi H, Doi H, Bando H, Ogura T, Sone S: Infrequent Presence of Anti-c-Myc Antibodies and Absence of c-Myc Oncoprotein in Sera from Lung Cancer Patients. Oncology 1999;56:129-133.

35 Mack U, Ukena D, Montenarh M, Sybrecht GW: Serum anti-p53 antibodies in patients with lung cancer. Oncol Rep 2000;7:669-674.

-36 Oshikawa K, Sugiyama Y: Serum anti-p53 autoantibodies from patients with idiopathic pulmonary fibrosis associated with lung cancer. Resp Med 2000;94:1085-1091.

-37 Cioffi M, Vietri MT, Gazzerro P, Magnetta R, D’Auria A, Durante A, Nola E, Puca GA, Molinari AM: Serum anti-p53 antibodies in lung cancer: comparison with established tumor markers. Lung Cancer 2001;33:163-169.

-38 Zhang JY, Casiano CA, Peng XX, Koziol JA, Chan EK, Tan EM: Enhancement of antibody detection in cancer using panel of recombinant tumor-associated antigens. Cancer Epidem Biomar 2003;12:136-143.

-39 Neri M, Betta P, Marroni P, Filiberti R, Cafferata M, Mereu C, Ivaldi G, Montanaro F, Puntoni R, Paganuzzi M: Serum anti-p53 autoantibodies in pleural malignant mesothelioma, lung cancer and non-neoplastic lung diseases. Lung Cancer 2003;39:165-172.

40 Sangrajrang S, Sornprom A, Chernrungroj G, Soussi T: Serum p53 antibodies in patients with lung cancer: correlation with clinicopathologic features and smoking. Lung Cancer 2003;39:297-301.

-41 Li Y, Karjalainen A, Koskinen H, Hemminki K, Vainio H, Shnaidman M, Ying Z, Pukkala E, Brandt-Rauf PW: p53 autoantibodies predict subsequent development of cancer. Int J Cancer 2005;114:157-160.

42 Megliorino R, Shi FD, Peng XX, Wang X, Chan EKL, Tan EM, Zhang JY: Autoimmune response to antiapoptotic protein survivin and its association with antibodies to p53 and c-myc in cancer detection. Cancer Detect Prev 2005;29:241-248.

\$3 Türeci O, Mack U, Luxemburger U, Heinen H, Krummenauer F, Sester M, Sester U, Sybrecht GW, Sahin U: Humoral immune responses of lung cancer patients against tumor antigen NY-ESO-1. Cancer Lett 2006;236:64-71.

44 Looi K, Megliorino R, Shi FD, Peng XX, Chen Y, Zhang JY: Humoral immune response to p16, a cyclindependent kinase inhibitor in human malignancies. Oncol Rep 2006;16:1105-1110.

-45 Titulaer MJ, Klooster R, Potman M, Sabater L, Graus F, Hegeman IM, Thijssen PE, Wirtz PW, Twijnstra A, Smitt PA: SOX antibodies in small-cell lung cancer and Lambert-Eaton myasthenic syndrome: frequency and relation with survival. J Clin Oncol 2009;27:4260-4267.

46 Tang k, Yue WT, Wang Y, Zhang LN, Xu SF: A new method to detect p53 autoantibodies in serum of patients with non-small cell lung cancer. Zhongguo Fei Ai Za Zhi 2009;12:969-974.

47 Ma L, Yue WT, Zhang LN, Wang Y, Zhang CY, Yang XH: Clinical significance and diagnostic value of Survivin antibody in patients with non-small cell lung cancer. Zhongguo Fei Ai Za Zhi 2010;13:706-712.

48 Murray A, Chapman CJ, Healey G, Peek LJ, Parsons G, Baldwin D, Barnes A, Sewell HF, Fritsche HA, Robertson JFR: Technical validation of an autoantibody test for lung cancer. Ann Oncol 2010;21:1687-1693.

49 Park Y, Kim Y, Lee JH, Lee EY, Kim HS: Usefulness of serum anti-p53 antibody assay for lung cancer diagnosis. Arch Pathol Lab Med 2011;135:1570-1575.

50 Chapman CJ, Thorpe AJ, Murray A, Parsykowalska CB, Allen J, Stafford KM, Chauhan AS, Kite TA, Maddison P, Robertson JF: Immunobiomarkers in small cell lung cancer: potential early cancer signals. Clin Cancer Res 2011;17:1474-1480.

51 Yu DH, Li JH, Wang YC, Xu JG, Pan PT, Wang L: Serum anti-p53 antibody detection in carcinomas and the predictive values of serum p53 antibodies, carcino-embryonic antigen and carbohydrate antigen 12-5 in the neoadjuvant chemotherapy treatment for III stage non-small cell lung cancer patients. Clin Chim Acta 2011;412:930-935.

52 Matsumoto T, Ryuge S, Kobayashi M, Kageyama T, Hattori M, Goshima N, Jiang SX, Saegusa M, Iyoda A, Satoh Y: Anti-HuC and -HuD autoantibodies are differential sero-diagnostic markers for small cell carcinoma from large cell neuroendocrine carcinoma of the lung. Int J Oncol 2012;40:1957-1962.

53 Chapman CJ, Healey GF, Andrea M, Peter B, Chris R, Peek LJ, Jared A, Thorpe AJ, Geoffrey HF, ParsyKowalska CB: EarlyCDT®-Lung test: improved clinical utility through additional autoantibody assays. Tumour Biol 2012;33:1319-1326.

54 Shan Q Lou X, Xiao T, Zhang J, Sun H, Gao Y, Cheng S, Wu L, Xu N, Liu S: A cancer/testis antigen microarray to screen autoantibody biomarkers of non-small cell lung cancer. Cancer Lett 2013;328:160-167. 


\section{Cellular Physiology Cell Physiol Biochem 2018;51:2631-2646

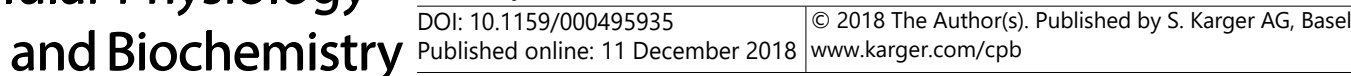 \\ Qin et al.: Diagnostic Performance of TAAbs in LC}

55 Zhang C, Ye L, Guan S, Jin S, Wang W, Sun S, Lee KH, Wei J, Liu B: Autoantibodies against p16 proteinderived peptides may be a potential biomarker for non-small cell lung cancer. Tumour Biol 2014;35:20472051.

56 Peng YH, Weng XF, Zhang LQ, Fang YS, Xu YW: Diagnostic value of tumor NY-ESO-1 autoantibody and PRDX6 combined with heat shock protein 70 in lung cancer. Journal of Chinese Practical Diagnosis and Therapy 2015;29:1024-1027.

-57 Doseeva V, Colpitts T, Gao G, Woodcock J, Knezevic V: Performance of a multiplexed dual analyte immunoassay for the early detection of non-small cell lung cancer. J Transl Med 2015;13:55.

-58 Yang J, Jiao S, Kang J, Li R, Zhang G: Application of serum NY-ESO-1 antibody assay for early SCLC diagnosis. Int J Clin Exp Pathol 2015;8:14959-14964.

59 Xing W, Zhang T, Xia LY, Sui TQ, Lu N, Cheng GH, Qin XF: Combined diagnostic value of multiple tumor associated autoantibodies in non-small cell lung cancer. Basic and Clinical Medicine 2016;36:656-660.

-60 Dai L, Tsay JCJ, Li J, Yie TA, Munger JS, Pass H, Rom WN, Zhang Y, Tan EM, Zhang JY: Autoantibodies against tumor-associated antigens in the early detection of lung cancer. Lung cancer 2016;99:172-179.

61 Oshima Y, Shimada H, Yajima S, Nanami T, Matsushita K, Nomura F, Kainuma O, Takiguchi N, Soda H, Ueda T: Erratum to: NY-ESO-1 autoantibody as a tumor-specific biomarker for esophageal cancer: screening in 1969 patients with various cancers. J Gastroenterol 2015;51:30-34.

-62 Li P, Shi JX, Xing MT, Dai LP, Li JT, Zhang JY: Evaluation of serum autoantibodies against tumor-associated antigens as biomarkers in lung cancer. Tumour Biol 2017;39:1010428317711662.

63 Peng W, Song C, Xie W, Hua Y, Wang K, Dai L, Yi Z, Zhang J: Evaluation of Diagnostic Value in Using a Panel of Multiple Tumor-Associated Antigens for Immunodiagnosis of Cancer. J Immunol Res 2014;2014:512540.

64 Cressey R, Pimpa S, Chewaskulyong B, Lertprasertsuke N, Saeteng S, Tayapiwatana C, Kasinrerk W: Simplified approaches for the development of an ELISA to detect circulating autoantibodies to p53 in cancer patients. BMC Biotechnol 2008;8:16.

65 Karanikas V, Khalil S, Kerenidi T, Gourgoulianis KI, Germenis AE: Anti-survivin antibody responses in lung cancer. Cancer Lett 2009;282:159-166.

66 Krause P, Türeci O, Micke P, Buhl R, Huber C, Sahin U: SeroGRID: an improved method for the rapid selection of antigens with disease related immunogenicity. J Immunol Methods 2003;283:261-267.

67 Maddison P, Thorpe A, Silcocks P, Robertson JFR, Chapman CJ: Autoimmunity to SOX2, clinical phenotype and survival in patients with small-cell lung cancer. Lung cancer 2010;70:335-339.

68 Yagihashi A, Asanuma K, Kobayashi D, Tsuji N, Shijubo Y, Abe S, Hirohashi Y, Torigoe T, Sato N, Watanabe $\mathrm{N}$ : Detection of autoantibodies to livin and survivin in Sera from lung cancer patients. Lung cancer 2005;48:217-221.

69 Stockert E, Jager E, Chen YT, Scanlan MJ, Gout I, Karbach J, Arand M, Knuth A, Old LJ: A survey of the humoral immune response of cancer patients to a panel of human tumor antigens. J Exp Med 1998;187:1349-1354.

70 Zhao F, Zhou QH, Wang LL, Wu Z, Liu LX, Wang Y, Liu J, FengWH: Dynamic changes of serum p53 antibody in patients with lung cancer before and after operation and its clinical significance. Chinese Journal of Lung Cancer 2000;3:253-256.

-71 Macdonald IK, Allen J, Murray A, Parsy-Kowalska CB, Healey GF, Chapman CJ, Sewell HF, Robertson JF: Development and validation of a high throughput system for discovery of antigens for autoantibody detection. PLoS One 2012; 7:e40759.

72 Liang ZK, Xu SF, Liu ZD, Zhou SJ, Song XY: Application of serum tumor markers in assistant diagnosis of lung cancer. Chinese Journal of Lung Cancer 2008:256-259.

73 Cai ZX: The value of Survivin antibody and its gene expression in the diagnosis of lung cancer. China Practical Medical 2013:50-51.

74 Sun SJ, Cui X: The value of serum survivin in the diagnosis of lung cancer. Seek Medical and Ask The Medicine 2013:165-167.

75 Yamaguchi K, Patturajan M, Trink B, Usadel H, Koch W, Jen J, Sidransky D: Circulating antibodies to p40(AIS) in the sera of respiratory tract cancer patients. Int J Cancer 2000;89:524-528.

76 Rohayem J, Diestelkoetter P, Weigle B, Oehmichen A, Schmitz M, Mehlhorn J, Conrad K, Rieber EP: Antibody response to the tumor-associated inhibitor of apoptosis protein survivin in cancer patients. Cancer Res 2000;60:1815-1817. 


\section{Cellular Physiology Cell Physiol Biochem 2018;51:2631-2646

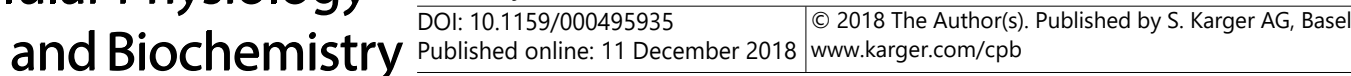 \\ Qin et al.: Diagnostic Performance of TAAbs in LC}

77 Hodson ME, Turnerwarwick M: Autoantibodies in patients with bronchial carcinoma. Thorax 1975;30:367370.

78 Kuemmel A, Simon P, Breitkreuz A, Röhlig J, Luxemburger U, Elsäßer A, Schmidt LH, Sebastian M, Sahin U, Türeci Ö: Humoral immune responses of lung cancer patients against the Transmembrane Phosphatase with TEnsin homology (TPTE). Lung Cancer 2015;90:334-341.

79 Wang J, Shivakumar S, Barker K, Tang Y, Wallstrom G, Park JG, Tsay JC, Pass HI, Rom WN, Labaer J: Comparative Study of Autoantibody Responses between Lung Adenocarcinoma and Benign Pulmonary Nodules. J Thorac Oncol 2016;11:334-345.

-80 Qi S, Huang M, Teng H, Lu Y, Jiang M, Wang L, Shi J, Ma Q Gu G, Xin Y: Autoantibodies to chromogranin A are potential diagnostic biomarkers for non-small cell lung cancer. Tumour Biol 2015;36:9979-9985.

-81 Wang W, Guan S, Sun S, Jin Y, Lee KH, Chen Y, Wei J: Detection of circulating antibodies to linear peptide antigens derived from ANXA1 and DDX53 in lung cancer. Tumour Biol 2014;35:4901-4905.

82 Dai N, Cao XJ, Li MX, Qing Y, Liao L, Lu XF, Zhang SH, Li Z, Yang YX, Wang D: Serum APE1 autoantibodies: a novel potential tumor marker and predictor of chemotherapeutic efficacy in non-small cell lung cancer. Plos One 2013;8:e58001.

83 Ma L, Yue W, Teng Y, Zhang L, Gu M, Wang Y: Serum Anti-CCNY Autoantibody Is an Independent Prognosis Indicator for Postoperative Patients with Early-Stage Nonsmall-Cell Lung Carcinoma. Dis Markers 2013;35:317-325.

84 Pedchenko T, Mernaugh R, Parekh D, Li M, Massion PP: Early detection of NSCLC with scFv selected against IgM autoantibody. Plos One 2013;8:e60934.

85 Zhang Y, Ying X, Han S, Wang J, Zhou X, Bai E, Zhang J, Zhu Q: Autoantibodies against insulin-like growth factor-binding protein-2 as a serological biomarker in the diagnosis of lung cancer. Int J Oncol 2013;42:93100.

-86 Ye L, Li X, Sun S, Guan S, Wang M, Guan X, Lee KH, Wei J, Liu B: A study of circulating anti-CD25 antibodies in non-small cell lung cancer. Clin Transl Oncol 2013;15:633-637.

-87 Yao Y, Yu F, Wu J, Wan H, Jing W, Lam S, Wan LL, Girard L, Gazdar AF, Wu Z: Potential application of nonsmall cell lung cancer-associated autoantibodies to early cancer diagnosis. Biochem Biophys Res Commun 2012;423:613-619.

88 Liu L, Liu N, Liu B, Yang Y, Zhang Q, Zhang W, Yu P, Jin Y, Guo J, Guan S: Are circulating autoantibodies to ABCC3 transporter a potential biomarker for lung cancer? J Cancer Res Clin Oncol 2012;138:1737-1742.

89 Jiang H: Dickkopf-1 autoantibody is a novel serological biomarker for non-small cell lung cancer. Biomarkers 2010;15:128-134.

90 Li Y, Yue WT, Wang Y, Zhang LN, Gu M, Xu SF: Study of EGFR autoantibodies in serum of patients with nonsmall cell lung cancer by peptide chip. Chinese Journal of Lung Cancer 2010;13:174-178.

$\$ 91$ Amornsiripanitch N, Hong S, Campa MJ, Frank MM, Gottlin EB, Jr PE: Complement factor H autoantibodies are associated with early stage NSCLC. Clin Cancer Res 2010;16:3226-3231.

92 Zhang XZ, Xiao ZF, Li C, Xiao ZQ, Yang F, Li DJ, Li MY, Li F, Chen ZC: Triosephosphate isomerase and peroxiredoxin 6, two novel serum markers for human lung squamous cell carcinoma. Cancer Sci 2009;100:2396-2401.

-93 He P, Naka T, Serada S, Fujimoto M, Tanaka T, Hashimoto S, Shima Y, Yamadori T, Suzuki H, Hirashima T: Proteomics-based identification of $\alpha$-enolase as a tumor antigen in non-small lung cancer. Cancer Sci 2007;98:1234-1240.

-94 Yang F, Zhiqiang Xiao, Xiuzhi Zhang, Li C, Pengfei Zhang, Maoyu Li, Chen Y, Geqin Zhu, Sun Y, Yingfu Liu A: Identification of Tumor Antigens in Human Lung Squamous Carcinoma by Serological Proteome Analysis. J Proteome Res 2007;6:751-758.

95 Pereira-Faca SR, Kuick R, Puravs E, Zhang Q Krasnoselsky AL, Phanstiel D, Qiu J, Misek DE, Hinderer R, Tammemagi M: Identification of 14-3-3 theta as an antigen that induces a humoral response in lung cancer. Cancer Res 2007;67:12000-12006.

-96 Zhong L, Coe SP, Stromberg AJ, Khattar NH, Jett JR, Hirschowitz EA: Profiling tumor-associated antibodies for early detection of non-small cell lung cancer. J Thorac Oncol 2006;1:513-519.

97 Chang JW, Lee SH, Jeong JY, Chae HZ, Kim YC, Park ZY, Yoo YJ: Peroxiredoxin-I is an autoimmunogenic tumor antigen in non-small cell lung cancer. FEBS Lett 2005;579:2873-2877.

-98 Zhang L, Liu J, Zhang H, Shanshan WU, Huang L, Dacheng HE, Xiao X: Discovery and identification of antiU1-A snRNP antibody in lung cancer. Sci China C Life Sci 2005;48:641-647. 


\section{Cellular Physiology Cell Physiol Biochem 2018;51:2631-2646 \begin{tabular}{ll|l} 
and Biochemistry Published onIIne: T1 December 2018 & $\begin{array}{l}\text { (c) } 2018 \text { The Author(s). Published by S. Karger AG, Basel } \\
\text { www.karger.com/cpb }\end{array}$ \\
\hline
\end{tabular} \\ Qin et al.: Diagnostic Performance of TAAbs in LC}

-99 Bazhin AV, Savchenko MS, Shifrina ON, Demoura SA, Chikina SY, Jaques G, Kogan EA, Chuchalin AG, Philippov PP: Recoverin as a paraneoplastic antigen in lung cancer: the occurrence of anti-recoverin autoantibodies in sera and recoverin in tumors. Lung Cancer 2004;44:193-198.

100 Brichory F, Beer D, Le NF, Giordano T, Hanash S: Proteomics-based identification of protein gene product 9.5 as a tumor antigen that induces a humoral immune response in lung cancer. Cancer Res 2001;61:79087912.

101 Graus F, Dalmou J, Reñé R, Tora M, Malats N, Verschuuren JJ, Cardenal F, Viñolas N, Garcia dMJ, Vadell C: Anti-Hu antibodies in patients with small-cell lung cancer: association with complete response to therapy and improved survival. J Clin Oncol 1997;15:2866-2872.

102 Yue W, Zhao X, Zhang L, Xu S, Liu Z, Ma L, Jia W, Qian Z, Zhang C, Wang Y: Cell Cycle Protein Cyclin Y Is Associated With Human Non-Small-Cell Lung Cancer Proliferation and Tumorigenesis. Clin Lung Cancer 2011;12:43-50.

103 Dalmau J, Furneaux HM, Gralla RJ, Kris MG, Posner JB: Detection of the anti-Hu antibody in the serum of patients with small cell lung cancer--a quantitative western blot analysis. Ann Neurol 1990;27:544-552.

104 Tsou JA, Kazarian M, Patel A, Galler JS, Lairdoffringa IA, Carpenter CL, London SJ: Low level anti-Hu reactivity: a risk marker for small cell lung cancer? Cancer Detect Prev 2009;32:292-299.

105 Jia J, Wang W, Meng W, Ding M, Ma S, Wang X: Development of a multiplex autoantibody test for detection of lung cancer. Plos One 2014;9:e95444.

106 Gao H, Zheng M, Sun S, Wang H, Yue Z, Zhu Y, Han X, Yang J, Zhou Y, Cai Y, Hu W: Chaperonin containing TCP1 subunit 5 is a tumor associated antigen of non-small cell lung cancer. Oncotarget 2017;8:6417064179.

107 Pilyugin MA-Ohoo, Descloux P, Andre PA, Laszlo V, Dome B, Hegedus B, Sardy S, Janes S, Bianco A, Laurent GJ, Irminger-Finger I: BARD1 serum autoantibodies for the detection of lung cancer. Plos One 2017;12:e0182356.

108 Dai N, Cao Xj, Li MX, Qing Y, Liao L, Lu XF, Zhang SH, Li Z, Yang YX, Wang D: Serum APE1 autoantibodies: a novel potential tumor marker and predictor of chemotherapeutic efficacy in non-small cell lung cancer. PLoS One 2013;8:e58001.

109 Tang ZM, Ling ZG, Wang CM, Wu YB, Kong JL: Serum tumor-associated autoantibodies as diagnostic biomarkers for lung cancer: A systematic review and meta-analysis. PLoS One 2017;12:e0182117.

110 Salgia R, Skarin AT: Molecular abnormalities in lung cancer. J Clin Oncol 1998;16:1207-1217.

111 Jett JR, Peek LJ, Fredericks L, Jewell W, Pingleton WW, Robertson JF: Audit of the autoantibody test, EarlyCDT(R)-lung, in 1600 patients: an evaluation of its performance in routine clinical practice. Lung cancer 2014;83:51-55.

112 Boyle P, Chapman CJ, Holdenrieder S, Murray A, Robertson C, Wood WC, Maddison P, Healey G, Fairley GH, Barnes AC, Robertson JF: Clinical validation of an autoantibody test for lung cancer. Ann Oncol 2011;22:383-389.

113 Lam S, Boyle P, Healey GF, Maddison P, Peek L, Murray A, Chapman CJ, Allen J, Wood WC, Sewell HF, Robertson JF: EarlyCDT-Lung: an immunobiomarker test as an aid to early detection of lung cancer. Cancer Prev Res (Phila) 2011;4:1126-1134.

114 Healey GF, Lam S, Boyle P, Hamilton-Fairley G, Peek LJ, Robertson JF: Signal stratification of autoantibody levels in serum samples and its application to the early detection of lung cancer. J Thorac Dis 2013;5:618625.

115 Paesmans M, Sculier JP, Lecomte J, Thiriaux J, Libert P, Sergysels R, Bureau G, Dabouis G, Van Cutsem O, Mommen P, Ninane V, Klastersky J: Prognostic factors for patients with small cell lung carcinoma: analysis of a series of 763 patients included in 4 consecutive prospective trials with a minimum follow-up of 5 years. Cancer 2000;89:523-533.

116 Iannuzzi MC, Scoggin CH: Small cell lung cancer. Am Rev Respir Dis 1986;134:593-608.

117 Ichinose Y, Hara N, Ohta M, Takamori S, Kawasaki M, Hata K: Comparison between resected and irradiated small cell lung cancer in patients in stages I through IIIa. Ann Thorac Surg 1992;53:95-100.

118 Janne PA, Freidlin B, Saxman S, Johnson DH, Livingston RB, Shepherd FA, Johnson BE: Twenty-five years of clinical research for patients with limited-stage small cell lung carcinoma in North America. Cancer 2002;95:1528-1538.

119 Wang G, Chen Q, Zhu Y, Ke D, Qian W, Song W: The value of specific neuronal anti-Hu antibody in the early diagnosis of small cell lung cancer. Zhonghua Jie He He Hu Xi Za Zhi 2002;25:732-735. 


\section{Cellular Physiology Cell Physiol Biochem 2018;51:2631-2646

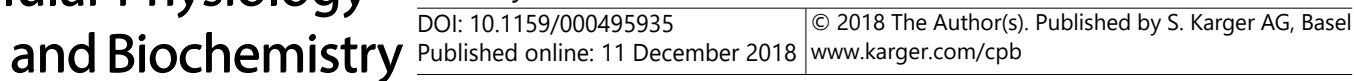 \\ Qin et al.: Diagnostic Performance of TAAbs in LC}

120 Mathew J, Healey G, Jewell W, Murray A, Chapman C, Peek L, Barnes A, Wood W, Robertson JF, Boyle P: Demographics of populations at high risk of lung cancer and results of the Early CDT-Lung test. Journal of Clinical Oncology 2010;28:15.

121 Guo G, Zhang Q, Yu Z, Li J, Ding Z, Li J, Tan W: Correlation between survivin genetic polymorphisms and lung cancer susceptibility. Int J Clin Exp Pathol 2015;8:7426-7430.

122 Rosato A, Menin C, Boldrin D, Dalla Santa S, Bonaldi L, Scaini MC, Del Bianco P, Zardo D, Fassan M, Cappellesso R, Fassina A: Survivin expression impacts prognostically on NSCLC but not SCLC. Lung Cancer 2013;79:180-186.

123 Rom WN, Goldberg Jd, Addrizzo-Harris D, Watson HN, Khilkin M, Greenberg AK, Naidich DP, Crawford B, Eylers E, Liu D, Tan EM: Identification of an autoantibody panel to separate lung cancer from smokers and nonsmokers. BMC Cancer. 2010;10:234.

124 Reuschenbach M, von Knebel Doeberitz M, Wentzensen N: A systematic review of humoral immune responses against tumor antigens. Cancer Immunol Immunother 2009;58:1535-1544.

125 Sangrajrang S, Sornprom A, Chernrungroj G, Soussi T: Serum p53 antibodies in patients with lung cancer: correlation with clinicopathologic features and smoking. Lung Cancer 2003;39:297-301.

126 Yongliang Li, Paul W. Brandt-Rauf, Walter P. Carney, Donald Y Tenney, Jean G Ford: Circulating anti-p53 antibodies in lung cancer and relationship to histology and smoking. Biomarkers 1999;4:381-390.

127 Lamp M, Saare M, Kadastik U, Karro H, Salumets A, Uibo R, Peters M: Survivin promoter polymorphisms and autoantibodies in endometriosis. J Reprod Immunol 2012;96:95-100. 